\title{
THE ISSUE OF ASIAN ORIGIN EXPATRIATES AS A PART OF THE DIVERSITY MANAGEMENT IN THE MORAVIAN-SILESIAN REGION
}

\author{
Martin Černek ${ }^{1}$, Kateřina Maková ${ }^{2}$ \\ ${ }^{1}$ Vysoká škola báňská-Technická univerzita Ostrava, Ekonomická fakulta, Sokolská tř́ida 33, 70121 Ostrava \\ Email:martin.cernekl@vsb.cz \\ ${ }^{2}$ Vysoká škola báňská-Technická univerzita Ostrava, Ekonomická fakulta, Sokolská třída 33, 70121 Ostrava \\ Email:katerina.makova@vsb.cz
}

\begin{abstract}
The paper deals with expatriates in the Moravian-Silesian region in the Czech Republic, with the issue of qualified expatriates as a tool for increasing the potential competitiveness of the enterprise. It is closely linked to the issue of the diversity management as an inherent part of the human resource management strategy. The success of the company is no longer characterized by the homogeneity of its personnel, but on the contrary it is very important to define the expatriates issue, their importance, mission and activities as well. The authors try to map corporate social conditions and to support theoretical approaches by the pilot empirical research. Moreover they investigate the degree of the adaptation to expatriates' "new" home. The main aim of the paper is to partially map the issue of Asian origin expatriates in the Moravian-Silesian region and to specify and complete the current theoretical background and diversity management relations.
\end{abstract}

Keywords: corporate social responsibility, diversity management, expatriates, integration, international companies, international management, Moravian-Silesian region.

JEL classification: M12, M14

Doručeno redakci: 22.11.2012; Recenzováno: 20.2.2013; 11.2.2013; 5.3.2013;Schváleno k publikování:19.6.2013

\section{Introduction}

Diversity management is a relatively new management approach that promotes diversity in the workplace as a mean of greater efficiency. Managers of organizations in a private or public sector try to find a way how to deal best with the increasing diversity of the workforce. However, this may be complicated in many cases. That's why the diversity management has become an integral part of the human resource management strategy. Diversity management gives employers a competitive advantage which is based on better exploiting of the individual potential. The experience shows that creating diverse teams and respecting personal and cultural differences give potential and specific benefits to companies. However, it is important to regard this distinction as an advantage during working in a team. People with different life experiences, different backgrounds, skills or interests may enrich the teamwork a lot. The issue of the diversity management has not been worked up in a depth in the Czech Republic yet. The authors wanted to approach the issue of expatriates in the Moravian-Silesian Region in this paper.

The Moravian-Silesian Region has belonged among the most important industrial regions of Central Europe since the 19th century. After 1989, there were significant changes in the Ostrava region in response to the changing political climate in the country. Nationwide industrial restructuring which leads to a significant downturn in industrial production, has a significant impact on the region. Most obvious steps include restrictions of coal mining and the decline of industrial giants such as Nová hut', Vítkovice, etc., which led to a huge increase of unemployment in the region. On the other hand, the decline in production and many important steps including ecological operations in companies have a very positive impact on improving the environment in the region. Many restructured enterprises have been bought by 
foreign investors. There are several industrial zones in the region, which are filled on the average up to $74 \%$. Existing industrial sites may be also used by domestic and foreign investors for new business plans. The authors try to map the issue of expatriates in the region by pilot probing (pre-survey) of selected sample of expatriates that maps their social, cultural and other conditions of their stay.

\section{The issue of expatriates}

Diversity management is closely related to issues of international management. It is, along with issues of international human resource management, very actual in the current globalizing world. It includes the employing process and people developing in the international or global organizations. International organizations and corporations, which run over activities in foreign affiliated companies, have different degree of autonomy due to the centralized parent company. This issue also includes expatriates management. These questions include the diversity of existing models of international organizations and the extent in which the policy and the practice of human resource management should be different in particular countries. Moreover there can be ranked the management problems in different cultures and environments and approaches used for selecting, developing and rewarding of expatriates. Armstrong (2006) claims that expatriates management is a major factor determining the success or failure of international business.

Expatriates are highly qualified experts who are usually sent by their parent companies to new foreign subsidiaries. Their goal is to build new plants or locations (Green Fields), projects of acquisitions or mergers of foreign companies.

It usually includes sending employees over to managerial positions abroad. The conception of "expatriation" and "expatriate" is derived from Latin. The prefix ex - "out" and the root of the word "patria" means "country". Deresky (2007) draws attention to the term transpatriate in this context, which replaces the expression "expatriate". Transpatriate is perceived in the context of the global environment reality. Expatriates, "transpatriates" according to Deresky, often change the target countries in which they act, therefore this prefix - trans. Thus expatriate is an employee who works abroad, respectively outside his/her home country, especially in subsidiaries or branches of multinational companies. Expatriate is usually sent abroad with the specific task on a so-called mission, when the period for sending is not precisely defined with regard to the planned time spent abroad, but also on the specific tasks that should be fulfilled during the mission.

Expatriates belong to a group known as the PCN (parent country nationals) by Perlmutter (1969) - members of the nationality of the country of origin, who usually work in headquarters before they are expatriated, i.e. sent to work abroad. The research, done by Kopp (1994), shows that e.g. the Japanese MNC (Multinational Corporation) employ the largest number of expatriates and American MNC the least.

Expatriates can be classified rather to ethnocentric approach where the management style, knowledge and assessment of employees and managers from the parent country are considered to be superior according to the Perlmutter (1969) typology of thought approaches to foreign executive (at present, international human resources strategy).

The logical consequence is that only managers of the parent country are considered suitably qualified and competent to work in top management, both within the parent headquarters and in individual branches. Human resources are therefore preferred from the home environment. 
This approach does not mean that the company is not aware of major cultural, geographic and political differences of values and conditions in which local staff are better oriented. However, a position at headquarters will be hardly offered in such companies within the ethnocentric approach.

The fact that firms often produce abroad only products with a lower technological level reflects particularly the ethnocentric approach within the formation of the management. Home environment and home employees are usually regarded as more competent to manufacture complex products and to use modern know-how.

However the results of author's research show that this characteristic is not necessarily the rule. Another feature of the ethnocentric approach is the acceptance of standards, procedures and performance requirements of the home country to the host country environment. This approach should ensure sharing of common corporate values, corporate culture and ensure the application of the same manufacturing processes. The ensurance of the global production program is typical.

The reasons for sending the employee over may be different, as well as the length of stay. Briscoe (1995) names the basic types of expatriates. The main criterion is the reason of sending the employee over. The traditional expatriate is characterized as an experienced older employee who is selected and sent abroad on the basis of his/her managerial or professional skills and knowledge. These employees are typically sent for one year to five years. It may also be so-called international cadres. Thus, employees who subsequently change their working stay as well as procedures and rarely return to jobs in their home country. In this case we are talking about permanent expatriates. Another type is a young, inexperienced expatriate, who is sent to the host country to require necessary work experience, usually for a period of six months to five years. The temporary expatriate is sent abroad for less than one year. Another type is a so called expatriate trainee, who is sent over to foreign affiliates for particular training, learning and integration into multinational companies. A specific form is a so-called virtual expatriate. It is a manager who is responsible for foreign affairs in the office, but in the fact he remains attendant in the home country. This manager controls specific foreign affairs through frequent telephone calls and videoconferencing.

Expatriates can be sent to the world according to the type of stay. Colakoglu and Caligiuri (2007) distinguish four basic types of stay:

- Technical type (which is aimed at the resolution of a highly professional problem in a foreign branch, for example IT specialists, technologists, etc.)

- Operation type (acts in a foreign branch in the middle management level. There are requirements for intercultural skills, communication competence because of the intense interaction with domestic employees).

- Development type (it is designed for acquiring of targeted skills and experience. The professional development of the expatriate is a primary objective of his/her stays abroad).

- Strategic type (It is the highest category of the stay. The aim is to occupy a key strategic role in the management in foreign subsidiaries. There are obviously highest demands on these types of expatriates. It is expected to have high intercultural and managerial competencies). 
Another approach to the classification of stays is the criterion of time. Nurney (2005) lists two types of stays: Short-term stay, which includes the stay of three to twelve months. Then expatriates return to their home country. They usually return to their original or similar place within the corporate hierarchy. The aim of the short-term expatriation is to fill a vacancy in a foreign branch relatively cheaply.

Financing costs are not usually as extensive as for long term stays. A short stay is not also very demanding on expatriate's intercultural and communication skills. Partners and children remain at the home country. Yates (2008) states the following main reasons for choosing short-term stays in comparison with long-term stays: fear of terrorist attacks and the uncertainty of security maintaining, the phenomenon of dual careers, when both partners or spouses have equally valuable or prospective employment and long-term expatriation would mean the end of a career of one of them and the third reason is the fear of subsequent repatriation.

The repatriation process - is a process of re-engagement of the returned expatriate to the branch or the headquarters, from which he/she originally traveled. This process entails various difficulties. Shenkar and Luo (2004) claim that most expatriates are paradoxically dissatisfied with the repatriation which parent companies provide to them or companies do not guarantee the repatriation. Most repatriates do not often know what their position in the parent company will be after their repatriation. It is a fact that if the expatriate leaves for several years, so the top management do not often know it, more to guarantee the repatriation. This problem is also reflected in the fact that about $25 \%$ of repatriates leave the company within one year after their return from a foreign stay. The reason is certain dissatisfaction, feeling of inadequate appreciation and insufficient re-integration into the company and society.

Long-term expatriation is usually negotiated for a period of one year to three years, sometimes even longer. Expatriate leaves abroad with his/her family in this case. Moreover the social and economic background is more complex and wider in this form of leaving. This also counts with suitable educational facilities for their children. A form of so-called virtual expatriation may be used in a case of some reluctance and fear of a long term stay and if it is allowed by practical circumstances.

For the reasons mentioned above, it is very difficult to decide whether it is needed to send expatriates or it is sufficient to use the local managers of the host country for meeting corporate strategic objectives. It is influenced by many factors. It is especially recommended to use expatriates in less developed countries, where there is a shortage of skilled workers with sufficient managerial skills. Or it is also recommended in a case of building or establishment of an entirely new foreign branch, when this "event" can not be handled without expatriates. As it has been already mentioned, employment of expatriates is much more expensive than hiring local people for the company. The high cost of expatriates lies primarily in the need for a compensation of disadvantages such as complications of traveling and living outside their own socio-cultural environment. As Armstrong (2006) states, expatriates are expensive. They can become three or four times more expensive than employment of the same people in the parent company. It is difficult to manage expatriates due to problems associated with the adaptation to the unfamiliar surroundings and working in it because of worries about their development and career problems emerging after their return to the parent company, etc. 
Advantages of expatriates' engagement can be primarily seen in their high-quality professional, managerial and diplomatic skills in a host country, likewise in knowledge of the overall organizational culture and structure of the company. On the other hand to hire local managers on management positions leads to lower labor costs, good knowledge of culture and social environment of the host country, knowledge of municipal and government policies, lower administrative burden of employment and the formation of a favorable relationship between local population and MNC. It is obviously related to the requirements imposed on the managers of multinational companies corresponding to the importance and impact of their work. In addition to the necessary high professional skill, they are expected to be willing to travel, work abroad, and adapt quickly in a different socio-cultural environment. It is linked to the overall decision problem of multinational corporations and companies how to train and prepare their staff with a high potential of transnational nature. Manager (expatriate) of a multinational corporation must be able to manage employees in an international environment, to plan, understand the dynamics of local and international business environment, be open to new suggestions, ideas, solutions and approaches, know the organizational context, culture and communicate efficiently and effectively.

Proper attention should be given to the issue of expatriates due to the numerous cultural, political, social, legislative, climate, etc., differences which the employees from the country of origin meet in foreign branches. Multinational companies should consider all possible factors that may affect the expatriates' success. The research (Deresky, 2007) shows that 44\% multinational companies increased the number of expatriates in recent years, but only $56 \%$ of these companies have a strategy to achieve success of the expatriation. The eventual expatriate failure is highly expensive. In addition, although secret, but widely known fact is that expatriated managers have higher salaries, which may be disincentive for local employees. Multinational companies send considerable number of expatriated managers, although a significant part of them fails in the host country. Black, Mendenhall \& Oddo (1991) argues that 16 - 40\% of U.S. expatriates returns prematurely from their foreign labor stay. According to Thomas (1998), the most common cause of premature return are working failure (inadequate job performance in the host country), lack of personal fulfillment, frustration from totally different socio-cultural environment, when the expatriate is alone in the host country. Strach (2009) argues that companies in many developing countries fumble with poorly prepared and qualified staff that is unable to conduct foreign operations effectively. Companies are forced to send their employees for these reasons from home headquarters to foreign subsidiaries. Expatriates do not only transfer knowledge, skills and experience, but they are a monitoring tool and also transfer corporate culture, philosophy, values and corporate objectives to foreign subsidiaries. The main reasons for expatriation of middle and top management are: the responsibility for technology transfer, introduction of the company on the market, office management, the transfer of corporate culture, the penetration on new markets and development of international communication skills (Rodrigues, 2008).

Ward (2001) considers expatriated managers to be key players in the global economy, who act as human links in the international business environment. They help to establish and maintain an environment of open communication, knowledge transfer, technology and know-how. Specific problems of the expatriation should be monitored especially on the economic and psychological level.

Maximum attention should be given to the choice of expatriates. Multinational companies generally expect cultural empathy, flexibility, adaptability, language skills, managerial skills, education, internal motivation and the personal maturity from expatriates. The successful 
expatriate should manage three basic types of skills according to managerial psychology: Personnel - that allow to overcome mental and emotional problems. Interpersonal - includes the ability to overcome barriers through effective communication and to establish the necessary relationships with other people. Sense - allow to understand the context of supporters' behavior from different cultures. The successful expatriate should be open to new suggestions, challenges and experiences.

Some companies use their own programs, which candidates have to pass in connection with the future expatriates' selection. It includes some assessment tools developed in the academic environment, but subsequently tested in an environment of firms. Štrach (2009) mentioned fourteen dimensions, which include: cultural sensitivity, business knowledge, courage, motivational skills, integrity, perspective, commitment, risk taking, feedback requesting, the use of feedback, cultural adventure, searching for learning opportunities, openness to criticism and flexibility. Kupka \& Everett (2008) e.g. base their assessment tool on the evaluation of the candidate's relationship to his homeland culture and to the culture of the host country. Only candidates with a positive feedback to both cultures meet the requirements for a successful expatriate mission. It is clear, from the psychological point of view, that a person who has a negative relationship, or does not show any respect to own or other culture will be integrated hardly into a new work and cultural environment. Another instrument, which generally helps companies to face potential failure of expatriates, is expatriates' training. It is a complex process that should take place throughout the employee expatriation. It usually follows after the selection phase and it is an important factor of expatriates' success in the foreign branch. Expatriates' training, which takes place in their home country before leaving, tries to prepare the employee for any potential problems which can be associated with a different society and culture. The content of the expatriate training may vary in different companies. It includes for example: ethnographic studies, cultural assimilators, meetings and communication with members of the host culture, language training, and psychological training focused on increasing resistance to stress. The training of future expatriates can be solved also by their repetitive sending to the host country on so-called business trips. It is necessary to note further important support of expatriates during their stay abroad which comes after their initial training. Mendenhall \& Stahl (2000) suggest three main categories of training and development of expatriates. These are: In-country real-time training - which is characterized as training throughout the expatriation. It is a particular extension of the predeparture intercultural training, when the classical training is inadequate. This type of training consists in the possibility of the socio-cultural issues assistance throughout the expatriation. It is based on the managers' needs to solve problems when they occur with the help of their "cultural trainer." A former expatriate or a colleague from the host country can be a coach.

Another type is so-called Global Mindset Training - a comprehensive approach which leads to the change perception of the society by a wide range of management and ordinary employees. Managers must learn to perceive their company as a global element and a part of the global environment. It is spoken about global education even in the context of the general education. Knowledge and experience of repatriates can be largely used in this context.

The third category of training and development is the self-education of expatriates with the usage of special software tools and the Internet. Nowadays there are many sites dedicated to the issue of expatriation. They can share their experiences, problems and experiences with others expatriates using the thematic web sites. The advantage is the easy accessibility and it is free of charge. 
According to Armstrong (2006) companies generally want to take the following steps to develop the education program for expatriates:

1. Identify the type of tasks abroad.

2. Carry out training needs analysis focused on the culture of the organization, analysis of the critical tasks of work and skills.

3. Establish learning objectives and criteria.

4. Create a program that would cover both general and specific cultural orientation.

5. Evaluate provided training.

The problem may occur with setting of some degree of mutual dependence and the interdependence of the parent company with operations abroad, as well as the decision whether to choose a local or foreign worker. Foreign manager is generally considered to be more capable of understanding the context of his/her branch with the company as a whole. However, if the foreign operation is relatively independent, the host management must be sufficiently autonomous. This idea is usually better realized by local managers. The complexity of internal processes in large companies leads to the need to involve employees from the mother country in the branch.

\section{Material and Methods}

There are several dozen of medium-sized and large international companies in the MoravianSilesian region. For the purpose of the pilot survey, the authors have chosen those firms that were willing to participate in the pilot probing for later, more comprehensive research of expatriates. It included getting feedback from the practice, the verification whether the respondents understand both research questions, and the meaning, importance and potential benefits of the research.

It was required to submit the following information to the empirical research due to the topic of the paper and its theoretical basis. In this case, the questionnaire method was chosen, which describes the goal of the work in the best way in this study. According to the selection of the methodological approach, the research questions were set out in the following topics:

1. Family and case history of expatriates

2. Socio-cultural case history of the expatriates

3. Professional and economic history case history of the expatriates.

\section{Results}

The pilot survey was carried out at ArcelorMittal Ostrava a.s. and Sungwoo Hitech s.r.o. with 22 respondents out of which $92 \%$ were men and $8 \%$ were women as seen in Figure 1 . All the interviewed expatriates from ArcelorMittal Ostrava a.s. were Indian nationality, interviewed expatriates from Sungwoo Hitech s.r.o. were Korean. Most of the respondents were younger than 30 years $(42 \%)$ and $25 \%$ of the respondents are at the age of $40-49$ years as assessed in Figure 2. 
Figure 1

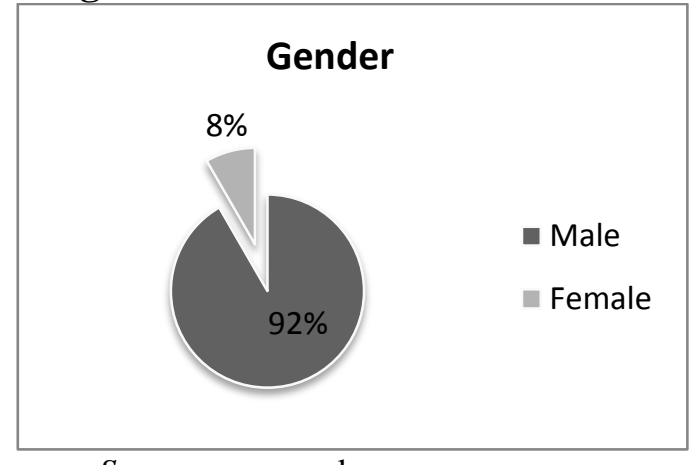

Source: own work.
Figure 2

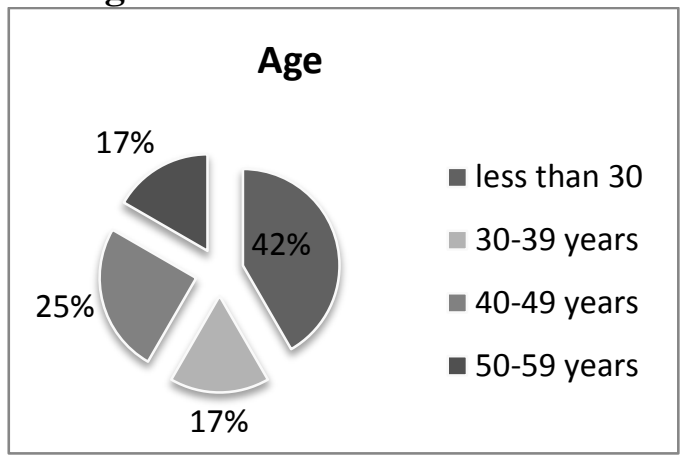

There were no expatriates with the secondary school leaving exam participating in the research, $83 \%$ of the respondents were graduates and $17 \%$ were postgraduates. $75 \%$ of the respondents studied a technical branch of study, $17 \%$ economic and there were $8 \%$ of the respondents who studied humanities as seen in Figure 3 and Figure 4.

Figure 3

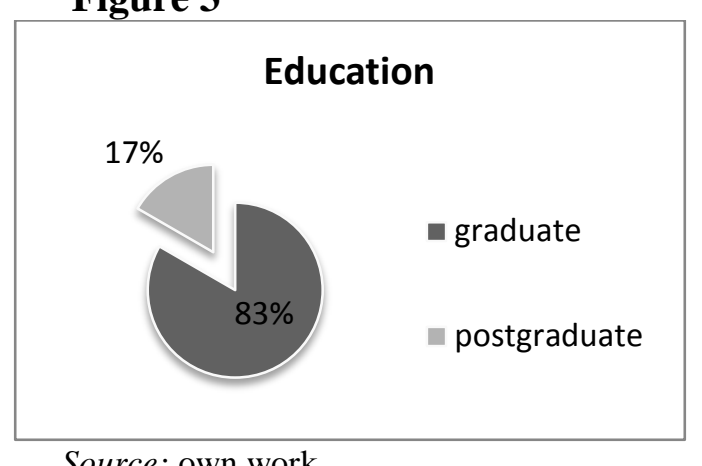

Source: own work.
Figure 4

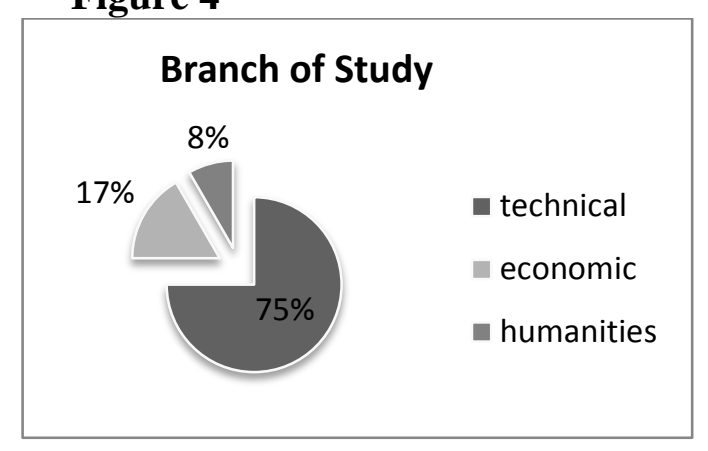

Most of the respondents (58\%) were married, $42 \%$ persons were single. No respondents chose the possible answer of being in a relationship in a common household or in a relationship, but not in a common household. Generally Indians and Koreans do not want to discuss their personal issues as the HR specialist warned, that's why some of them did not answer the question related to the number of children in the common household. Most of the respondents (42\%) are childless; there were no respondents with one child, $25 \%$ with three children and $17 \%$ with two children.

When the respondents were asked how long they had been working at ArcelorMittal Ostrava a.s. or Sungwoo Hitech s.r.o., most of them answered than less than a year (42\%), $33 \%$ of the respondents had worked in the selected company from one to 5 years, $17 \%$ had worked there even 11-20 years and only $8 \%$ of the respondents had worked at the company 6-10 years, as it is evident from Figure 5. 
Figure 5

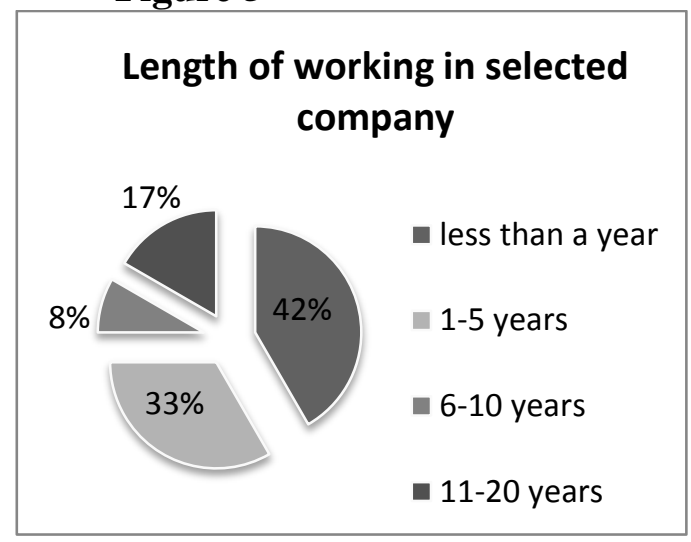

Source: own work.
Figure 6

\section{Main advantages of working in the Czech Republic}

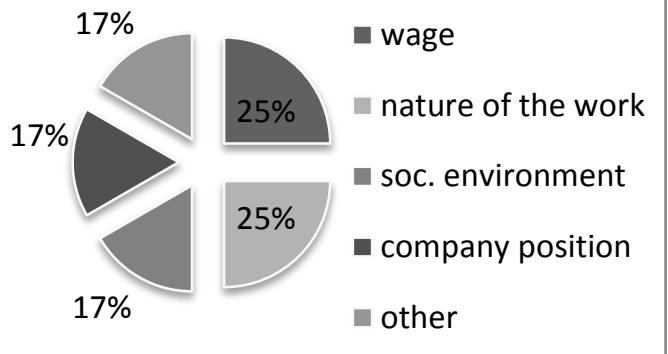

Figure 6 summarizes what the main advantages of working in the Czech Republic for expatriates are. $25 \%$ of the respondents ranked the wage and the nature of work among the main advantages. The social environment or the company position on the market were the reason for $17 \%$ of the respondents, other $17 \%$ of the respondents reported the advantage of travelling in Europe easily for personal purposes or the personal career chance. On the other hand the different social environment and the language barrier are ranked among the main disadvantages of working in the Czech Republic.

The positive result following from the survey was that $75 \%$ of answering expatriates were satisfied with conditions of work in the Czech Republic and $25 \%$ the respondents answered this question "rather yes". When the respondents were asked to report what problems are the most significant in relation to their stay in the Czech Republic, $75 \%$ of them reported the language barrier, $17 \%$ stated the cultural differences and $8 \%$ stated the social problem as seen in Figure 7.

Figure 7

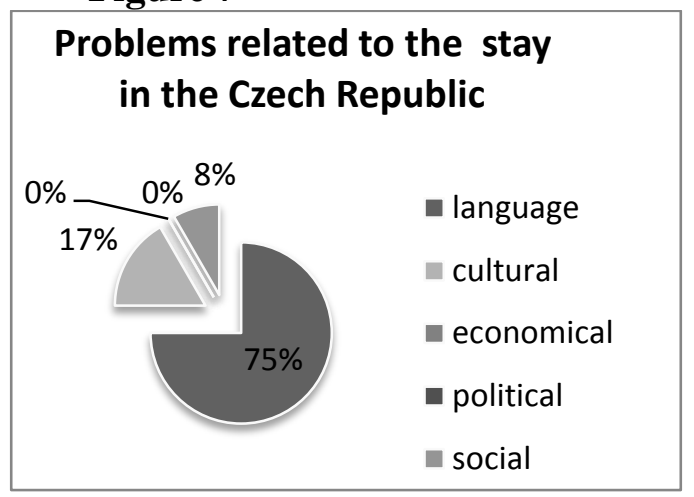

Source: own work.
Figure 8

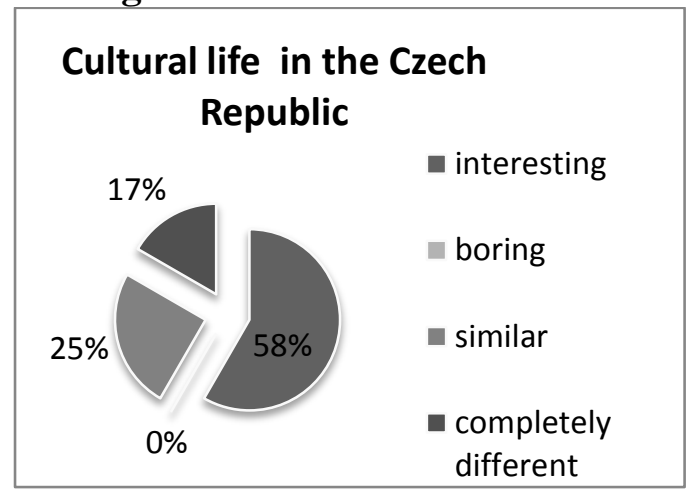

As it results from Figure 8, the respondents mostly evaluated the cultural life in the Czech Republic, compared with the culture in their country, as interesting (42\%). $33 \%$ of expatriates thought that the cultural life was similar in both countries and $25 \%$ of the respondents thought that the cultural life was completely different.

Next part of the survey was related to discrimination. As it is evident from Figure 9, $75 \%$ of the respondents sometimes felt underprivileged, $25 \%$ of the respondents have never felt underprivileged and there were no respondents who often felt underprivileged. As you can 
see in Figure 10, the discrimination was, according to the respondents, related to the race $(43 \%)$, the nationality $(36 \%)$, culture $(14 \%)$ and the language $(7 \%)$.

\section{Figure 9}

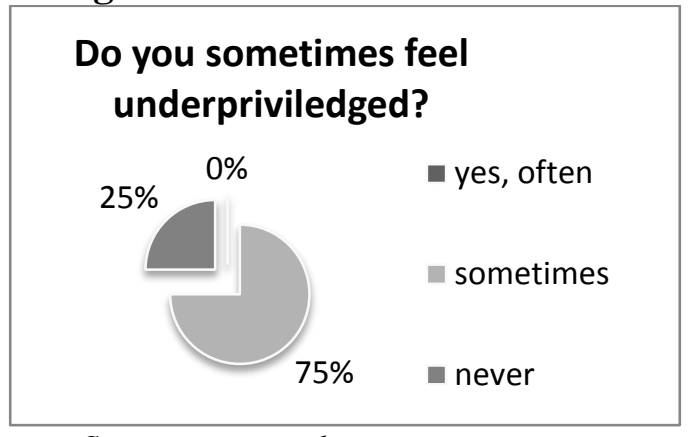

Source: own work.
Figure 10

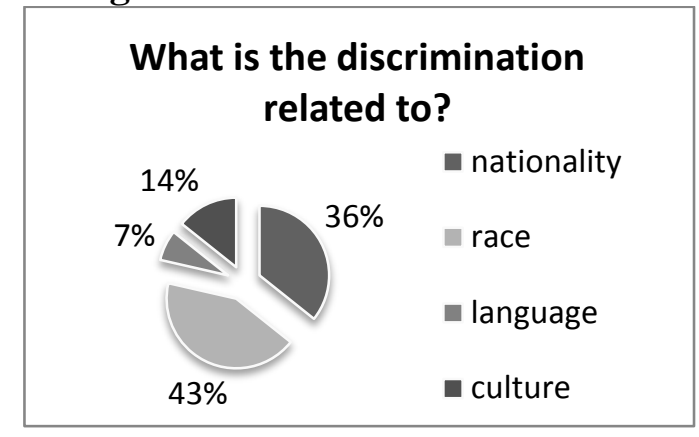

The respondents described their relationship with Czech citizens as good (83\%) and even 17 $\%$ of them marked it as very good. There were no respondents who considered their relationships with Czech citizens as bad or very bad as seen in Figure 11. On the other hand $67 \%$ of them rarely spend their leisure time with Czech colleagues, $8 \%$ of the respondents extraordinarily spend their leisure time with them and only $25 \%$ of the respondents often spend their leisure time together (see Figure 12).

\section{Figure 11}

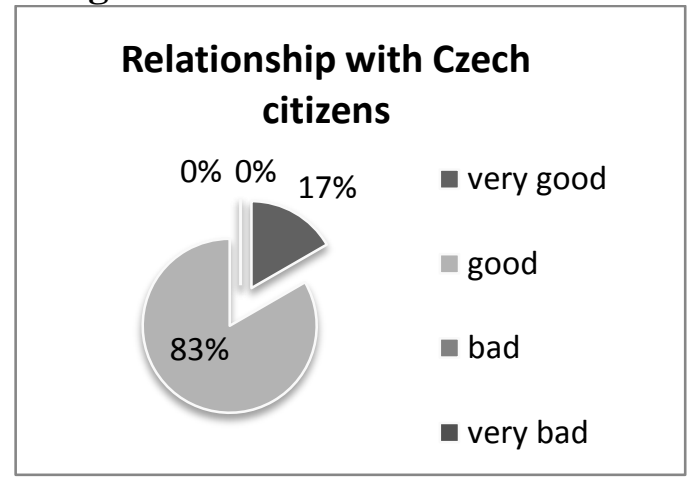

Source: own work.

\section{Figure 12}

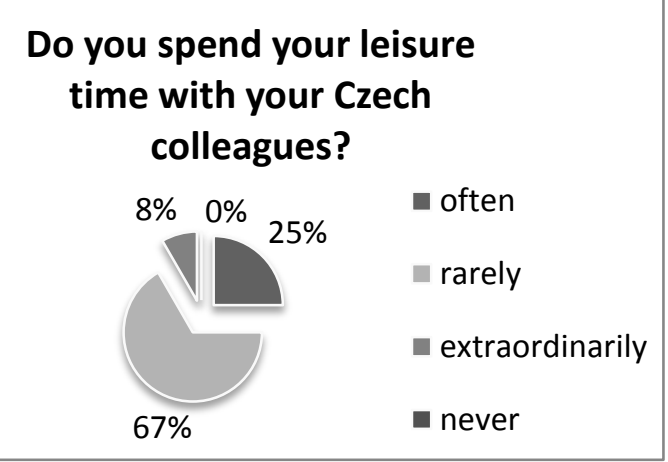

It is difficult to join family and professional life for many employees, that's why the respondents were asked about it. For $50 \%$ of them sometimes it is difficult, for $33 \%$ of the respondents it is almost always difficult and $17 \%$ marked the answer "never" (see Figure 13). Moreover $83 \%$ of the respondents thought that they worked harder than their Czech colleagues, $17 \%$ thought that it was similar and no of them marked the possibility that Czechs worked harder (see Figure 14). 
Figure 13

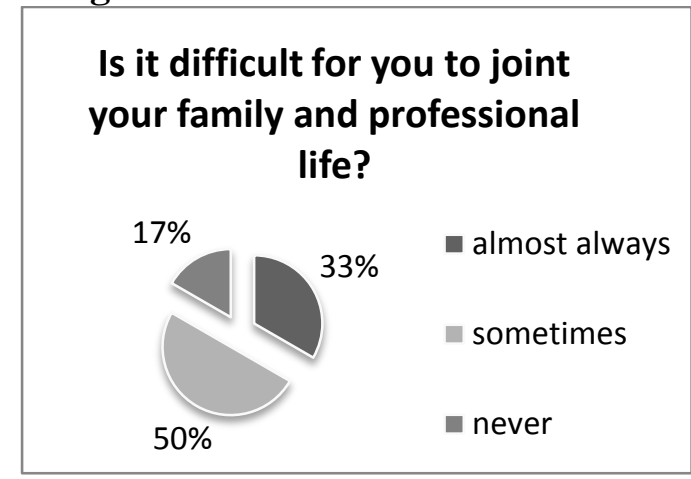

Source: own work.
Figure 14

Do you think you work

harder than your Czech colleagues?

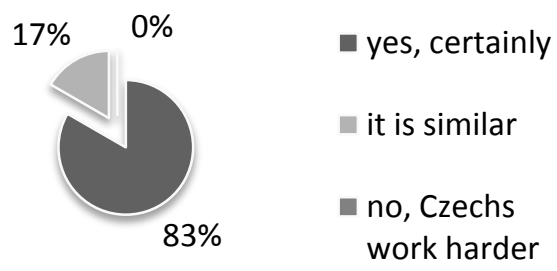

The main problem of Czech companies on the market is that the companies are not flexible enough, according to $58 \%$ of the respondents. As seen in Figure 15, $17 \%$ of them thought that the problems of Czech companies on the market were high prices of goods and services and low motivation of employees. Some respondents $(8 \%)$ thought that there was no competition among Czech companies.

Half of the respondents assumed that they would stay in the Czech Republic for a couple of years and half of them only for the necessary period. There were no respondents who assumed to stay in the Czech Republic forever.

Figure 15

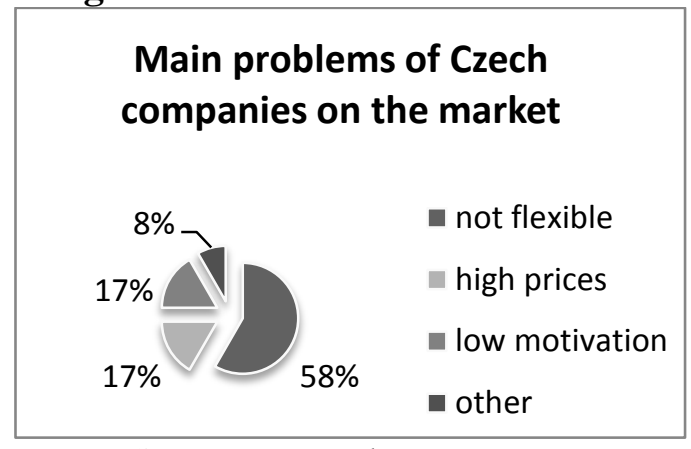

Source: own work.
Figure 16

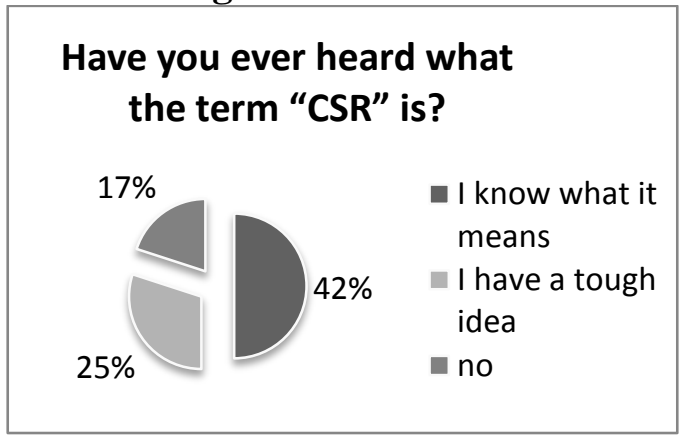

Moreover the respondents were asked if they had ever heard what the term "Corporate Social Responsibility" is. As seen in Figure 16, $42 \%$ of the respondents knew what the term means, $25 \%$ of them had only a tough idea and $17 \%$ have never heard this term. Those of them who knew what the term is, were asked to assess what the Corporate Social Responsibility implemented by their company is. Most of them (60\%) thought that CSR implemented by the company is reasonable, $40 \%$ of the respondents thought that the level was high.

\section{Discussion}

The authors tried to describe and briefly explain the expatriate issue in the theoretical part within the framework of international management and social diversity in the MoravianSilesian region in the Czech Republic. As already mentioned, the practical part is only a pilot probing, the authors plan, after modifying the questionnaire, to enlarge the research and implement semi-structured interviews, which would be consequently analyzed on qualitative data analysis by software Atlas.ti. The authors will gradually try to map out the expatriates issues in other regions as well. 


\section{Conclusion}

The main aim was to partially map the issue of diversity management in a selected sample of Asian expatriates in the Moravian-Silesian region. The applied questionnaire survey enabled to obtain necessary data to determine the following conclusions, as well as gathering data for further field investigation.

The expatriates issue is, in terms of global economy and the possibilities of penetrating on international markets, more than up-to-date. It can be claimed that the selected research sample of the respondents represents a general characteristic of expatriates. They are highly qualified professionals who were sent by their parent companies within managing their business in an international environment in both cases. It was a case of taking control of the personnel restructuring in the case of expatriates in ArcelorMitall Ostrava a.s., while expatriates in Sungwoo Hitech s.r.o. built their corporate office on a green field in the industrial zone Ostrava. The research sample of the respondents includes both traditional expatriates - older and more experienced, and also expatriates relatively young, who have less life and practical experience, but with fewer social obligations. It is a long-term expatriation in both cases, there was not form of temporary or a virtual expatriate.

Although most expatriates reported the university education of a technical type, it can not be accurately determined which of the mentioned theoretical types prevails. The authors did not deal with the issue of repatriation in this probing; it will be only part of the main research. The eventual preparation (training) of expatriates on the stay in the Czech Republic will be included in personal semi-structured interview as well.

\section{References}

[1] ARMSTRONG, M., 2006. A Handbook of Human Resource Management Practice. London: Kogan Page Limited. ISBN 9780749446314.

[2] BORBÁS, L., 2006. EU's Enterprise policy to improve Europe's competitiveness. 4th International Conference on Management, Enterprise and Benchmarking. Budapest, 2006, pp. 341-350. ISBN 978-963-216-270-6.

[3] BRISCOE, D. R., 1995. International Human Resource Management. New Jersey: Englewood Cliffs. ISBN 978-01319-100-89.

[4] CALIGIURI, P. M. a S. COLAKOGLU, 2007. A strategic contingency approach to expatriate assignment management. Human Resource Management Journal, 17(4), 393410. ISSN 0954-5395.

[5] DERESKY, H., 2007. International Management: Managing Across Borders and Cultures. New Jersey: Prentice Hall. ISBN 978-0136143260.

[6] KOPP, R., 1994. Rice-paper Ceiling: Breaking Through Japanese Corporate Culture. California: Stone Bridge Press. ISBN 1880656140.

[7] KUPKA, B. a A. M., EVERETT, 2008. Moscow on the Hudson: Assessing expatriates affective fit in host cultures with the intercultural communication affinity scale. European Journal of International Management, 2(3), 35-39. ISNN 1751-6757.

[8] MENDENHALL, M. E. a G. K. STAHL, 2000. Expatriate training and development: Where do we go from here? Human Resource Management, 39(2-3), 251-265. ISSN 0090-4848. 
[9] NURNEY, S. P., 2005. The long and short of it: when transitioning from a short-term to a long-term expatriate assignments, consider the financial implicatons. HR Magazine. Retrieved 14. 8. 2009 from the World Wide Web: http://allbusiness.com/humanresources/workforce-management/358163-1.html.

[10] PERLMUTTER, H. V., 1969. The Tortuous Evolution of the Multinational Corporation Columbia Journal of World Business, 4(1), 9-18. ISSN 0022-5428.

[11] RODRIGUES, C., 2008. International Menagement: A Cultural Approach. Thousand Oaks: Sage Publications. ISBN: 978-1-4129-5141-8.

[12] SHENKAR, O. a Y. LUO, 2004. International Business. West Sussex: John Wiley \& Sons. ISBN 978-1-4129-4906-4.

[13] ŠTRACH, P., 2009. Mezinárodní management. Praha: Grada. ISBN 978-80-247-29879.

[14] THOMAS, D. C., 1998. The expatriate experience: A critical review and synthesis. Advanced in International Comparative Management, 12, pp. 237-273. ISSN 07477929

[15] WARD, C., 2001. The psychology of culture shock. Hove: Routledge. ISBN 0-20399225-3.

[16] YATES, J., 2008. Global Mobility Trends: Short vs. Long Term Assignments. International Relocating Business. Retrieved 6. 9. 2009 from the World Wide Web: http://blog.sirva.com/blog/international-relocating-business. 